\title{
Marketing strategies for closing the market access gap experienced by small craft producers in South Africa
}

\author{
KM Makhitha \\ Department of Marketing and Retail Management \\ Pretoria, University of South Africa
}

\section{Keywords}

Craft producers, marketing planning, marketing strategy, small and medium enterprises (SMEs)

\begin{abstract}
The purpose of this paper was to determine the need for a marketing strategy on the part of small craft producers in South Africa. Existing literature on marketing planning and the local craft industry was used to prove that craft producers need marketing strategy planning to overcome the market access challenges they currently experience. Craft producers lack access to the market and need to formulate appropriate marketing strategies in order to overcome this obstacle. A marketing strategy impacts positively on business sales and the profitability of a business, and is the backbone of any enterprise, regardless of size. However, craft producers need an understanding of the market for them to formulate an effective and efficient marketing strategy.
\end{abstract}

Corresponding author: KM Makhitha

Email addresses for the corresponding author:makhikm@unisa.ac.za

First submission received: $24^{\text {th }}$ May 2018

Revised submission received: $15^{\text {th }}$ August 2018

Accepted: 10 th December 2018

\section{Introduction}

Craft producers in South Africa have limited access to markets (Department of Sports, Arts, Recreation \& Culture [DSARC], 2007; Hay, 2008; Makhitha, 2016; Makhitha \& Bresler, 2011). They struggle to market their products competitively, and also face competition from foreign craft producers (DSARC, 2007). The local craft industry is further crippled by a lack of reliable and accessible research data (Department of Economic Development [DED], 2009), which impedes the industry's development and competitiveness. Craft producers do not determine which products to sell to which target market. Since different markets have different needs, producers should determine the needs of each, before deciding which to focus on by offering products that can meet their unique needs (Makhitha, 2016). This requires that they do marketing planning, such that all aspects of marketing activity are carefully coordinated and integrated (Carson \& Cromie, 1990).

Owing to the diversified nature of the craft industry, there is no universally accepted definition for 'crafts'. In South Africa, the craft market encompasses "the creation and production of a broad range of utilitarian and decorative items produced on a small scale, with hand processes being the significant part of the value-added content. The production of goods uses a range of natural and synthetic materials" (Department of Arts, Culture, Science \& Technology [DACST], 1997). Crafts are also known as handicraft or artisanal products, which are defined as those produced by artisans, either completely by hand, or with the help of hand tools or even mechanical means, as long as the direct manual contribution of the artisan remains the most substantial component of the finished product. These are produced using raw materials from sustainable resources. The special nature of artisanal products derives from their distinctive features, which can be utilitarian, aesthetic, creative, culturally attached, decorative, functional, religiously and socially symbolic and significant. (Unesco, 1997)

Craft products include a wide range of items such as home furnishings, jewellery, fashion and fashion accessories, novelties and (corporate) gifts, garden and outdoor products, curios and collectibles, one-of-a-kind high-value individually made products, and indigenous artefacts which are culturally derived products (Department of Labour [DoL], 2011; Department of Trade and Industry [DTI], 2005). 
Although research has been conducted by national and provincial governments (Cape Craft and Design Institute [CCDI], 2008; DSARC, 2007; DTI, 2005; Wesgro, 2000), the data have merely served to identify and define craft products and businesses, as well as problem areas and challenges experienced in that industry. Grobler (2005) investigated the level of understanding of consumer behaviour among people participating in community craft projects, and the findings showed that project owners/managers lack an understanding of consumer behaviour. This, in turn, leads to the formulation of ineffective and inappropriate marketing and product strategies being targeted at end consumers. Hay (2008) concurs that craft producers do not respond to market demands, which prevents them from accessing the market successfully. Marketing planning could be useful for craft producers, in that they will have plans in place on how to market their products effectively. With marketing planning, businesses formulate appropriate marketing strategies to compete in the market (Sengupta \& Chattopadhyay, 2006), since they are able to respond to rapid changes in that environment (Gray \& Mabey, 2005).

\section{The craft industry in South Africa}

The development of the craft industry is a key strategy of the South African government, as far as sustainable development and the creation of employment opportunities are concerned (DoL, 2011). The industry also contributes to economic growth and environmental stewardship (United Nations [UN], 2010), as evidenced by government initiatives, research, projects and entities that have been initiated in support of the industry: examples include the Cultural Industries Growth Strategy (DACST, 1998), the Sector Development Strategy (DTI, 2005), Gauteng Creative Industries: Craft Sector and the Gauteng Craft Development Strategy (DSARC, 2007), as well as the development of the KwaZulu-Natal Integrated Craft Hub (DED, 2009).

There is an increasing demand for craft products globally, especially for home accessories and décor, gifts and products for garden and outdoor living, which are used simultaneously for decorative and functional purposes (United States Agency for Industrial Development [USAid], 2006). The rise in final customers' disposable incomes, and the tendency to accessorise and restyle homes with unique articles, are major driving factors in the surge in demand for crafts and decorative products (Frost \& Sullivan, 2005). In this country, recent decades have seen the opening of many homeware stores such as PepHome, @Home, @Home Living Space and Mr Price Home, as well as Woolworths' Artistic Collection departments, which operate from inside Woolworths branches. All these retailers sell handcrafted products, which create opportunities for craft producers who also target craft retailers.

The craft industry is dominated by small and medium enterprises (SMEs) (Hay, 2008) that are often unable to achieve the economies of scale that drive competition in many markets. It is difficult to create or sustain an industry association in the sector (DoL, 2008). The industry, which contributes R2 billion to the gross domestic product (GDP) in the craft industry value chain (Kaiser \& Associates, 2005), consists of over 7000 craft producer enterprises (DTI, 2005) and employs around 40000 people (DED \& SEDA, 2007 cited in McCarthy \& Mavundla, 2009). The local market has shown strong growth of between three and four per cent annually, while the sector contributes 0.14 per cent of the GDP, of which R150 million is derived from export sales. Between 2001 and 2003, the government spent R97 million on the establishment and growth of the local craft industry (Create SA, 2004 cited in Grobler, 2005), emphasising the importance of this sector.

\section{Problem statement and objectives}

The craft industry, which is dominated by small and medium craft producer organisations (Hay, 2008:2), is crippled by a lack of reliable and accessible research data (DED, 2009:3), which impedes the industry's development and competitiveness. According to the DSARC (2007:35, 67), marketing and branding are among the major challenges facing local craft producers.

Craft producers experience difficulties selling to craft retailers, who purchase only 36 per cent of craft products from this country (DSARC, 2007:129). These producers have limited access to the market (Wesgro, 2000:33), since the foreign craft producers whom they compete with, are far more resourceful (DSARC, 2007:35). Craft producers therefore need to determine which marketing strategies can close the 'lack-of-market-access' gap that they experience. Marketing strategy is the backbone of every business, 
and this research aims to determine which marketing strategies can help to close the market access gap confronting craft producers in this country.

\section{Literature Review \\ SMEs and marketing}

Traditionally, marketing has been associated with large enterprises, yet a number of studies have focused on SMEs and have illustrated the importance of marketing in their success (Gilmore, Carson \& Grant, 2001; Hills, Hultman \& Miles, 2008; Simpson, Padmore \& Taylor, 2001; Zontanos \& Anderson, 2004). Evidence shows that marketing is often underutilised and misunderstood by owner-managers of SMEs (Zontanos \& Anderson, 2004) and that marketing in those enterprises tends to be restricted by resource constraints in respect of finance, personnel, perceptions of related functions, and skills and attitudes towards marketing (Opuke, Abratt, Bendixen \& Pitt, 2005; Simpson \& Taylor, 2002; Wong \& Merilees, 2005; Zontanos \& Anderson, 2004). An SME's owner-manager is also a decision maker who manages and attends to other functions within the business (Berthon, Ewing, \& Napoli, 2008). However, SMEs need to create competitive advantage by formulating marketing strategies that are different from those of their competitors (Moriarty, Jones, Rowley \& Kupiec-Teahan, 2008). They have to implement marketing activities if they are to grow and survive (Van Scheers, 2011; Zontanos \& Anderson, 2004).

Marketing plays a leading role in SMEs in comparison with other functions pertaining to overall planning (Brooksbank, Kirby, Taylor \& Jones-Evans, 1999). It helps businesses create competitive advantage through differentiating their marketing strategies, which can be achieved by leveraging superior knowledge of customers, markets and technologies (Hills et al., 2008). Despite this, marketing remains a challenge for many SMEs (Van Scheers, 2011) as it is not formally planned for. Yet small business success is dependent not only on the presence of products and markets, but on the efficient marketing of products within those markets (Smith, 1990).

SMEs are generally known to have informal marketing plans (Izvercian, Miclea \& Potra, 2016) which are short-term in nature and involve informal, unplanned activities that mainly rely on the intuition and energy of the owner-manager (Blankson \& Stokes, 2002:49). Since SME owners and managers experience challenges with marketing, lack access to finance and business skills, as well as the knowledge, experience and time required (Simpson \& Taylor, 2002:379), the practice of marketing planning is usually limited. Small businesses further lack the ability to conduct formal marketing research and segmentation studies, which in turn limits their marketing and selling (Tang, Wang \& Zhang, 2007).

SME marketers may consider marketing as a synonym of either advertising or selling basic marketing concepts such as segmentation, targeting, positioning, customer orientation and seeking competitive advantage - concepts which are applicable to small as well as large entities (Awan \& Hashmi, 2014). Some SMEs prioritise marketing, while others regard it as having almost no role. The former entities tend to adopt a long-term approach to planning, while the latter tend to adopt a medium-term approach, and use simple budgeting in their marketing planning (Siu, Fang \& Lin, 2004).

Small, medium and micro enterprises (SMMEs) (generally referred to as SMEs) play a vital role in the economic development of any country (Muhammed, Char, Yasoa \& Hassan, 2010). SMEs fulfill a number of roles, ranging from poverty alleviation and employment creation to boosting international competitiveness. According to Lekhanya (2010), SMEs have become a critical solution for uplifting the standard of living in South Africa, owing to low economic growth, high unemployment and unsatisfactorily high levels of poverty in this country, particularly in the rural areas. SMEs, which are usually defined in terms of employment or the turnover they generate (Rogerson, 1999), have fewer than 250 employees. Over 90 per cent of all firms (including listed companies) in South Africa are classed as SMEs, thus it is accepted that local businesses with an annual turnover of less than R50 million should be classed as SMEs (Blueprint Strategy \& Policy, 2005).

\section{Marketing strategy}

Marketing strategy is a marketing activity that specifies both a target market and its related marketing mix elements/activities, such as product, promotion, price and place (distribution) (McCarthy \& Perreault, 1999). Walker, Mullins and Larréché (2008) describe a marketing strategy as specifying the target market for a particular product/product line and ensuring that all marketing mix elements are 
integrated (for competitive advantage) and tailored to meet customers' needs. It determines how an enterprise plans to compete against its major rivals and involves determining the competitive advantages which may arise as a result of the enterprise's ability to perform better than its competitors in certain areas. For example, an enterprise might perform better on product quality, distribution or cost cutting (Venter \& Janse van Rensburg, 2009). Usually, the marketing strategy is documented in a marketing plan, which guides the day-to-day running of operational marketing activities. Such plans allow enterprises, such as craft producers, to continuously evaluate the delivery of value in each market segment, and to determine whether such delivery is in line with their proposed value propositions and marketing objectives, as well as the expectations of customers (Venter \& Janse van Rensburg, 2009). Large businesses are more likely to have a formal marketing plan than smaller businesses (Coviello, Brodie \& Munro, 2000). However, small businesses are not exempted from doing marketing planning, since such planning has an impact on the sales and profit of the business (Sengupta \& Chattopadhyay, 2006).

Owing to the intensity of competition and changing market and customer requirements, businesses need to adapt their marketing activities to reflect these changes. Awan and Hashmi (2014) observe that businesses compete in an environment that is global in nature and scope, information-rich and knowledge-based - factors which continue to influence the way they operate. This requires that businesses adapt their marketing strategy in response to changes in the marketing environment.

Market segmentation is a process by which a market is divided into distinct subsets (segments) of customers with similar needs and characteristics (Lamb et al., 2011:178). These distinct needs and characteristics result in customers responding positively to a particular product offering and marketing mix strategy. Businesses are increasingly under pressure to improve their understanding of customers and their needs, because different customers have different needs, which also change from time to time (Cravens \& Piercy, 2009:83). Businesses must therefore determine not only the segments, but also the number of segments they choose to pursue.

Businesses make decisions on the products they intend to offer, the breadth or diversity of the product lines, the level of technical sophistication and the target level of product quality, relative to that of their competitors (Walker et al., 2008). Such decisions involve deciding on matters such as branding, packaging, product development/improvements and service-level decisions (Alsen, 2007). These decisions are closely linked to their analysis of the market and their market selection, which require environmental analysis prior to a decision being made (Hutt \& Speh, 2007).

Marketing communication is another element of the marketing strategy which requires that craft producers understand how they will communicate information about their products and businesses to the market. Unless customers know about the craft producers' existence and the products they carry, they will not buy their products. Marketing communication is a means by which a business attempts to inform, persuade and remind consumers, directly or indirectly, about the products and brands they sell (Keller, 2009:141). The elements of a marketing communication strategy include advertising, sales promotion, public relations, personal selling, exhibitions, telemarketing and direct marketing tools (Dwyer \& Tanner, 2009:296, 316-317).

The craft industry is characterised by the low demand for goods, as a result of the low purchasing power of its customers. Craft producers therefore need to price their products such that consumers can afford them, while at the same time producing products that are of good quality. Price is a key determinant of performance, since it has the biggest impact on the amount of profit a business makes. Businesses must thus determine appropriate prices, if they are to attract more customers and retain existing ones (Sije \& Oloko, 2013).

Businesses make decisions on how their product(s) will be made available to a chosen target market, and when, where and for how long such products will be made available. Channels of distribution help craft producers make the right product at the right time, at the right place, while satisfying customer requirements (Hilletofth, 2009). Craft producers must make a choice regarding which distribution channels will be most effective in getting their products and services to the market, while taking into consideration their competitors, their market position and the specific situation of their target segment (Urbańska, 2016). They also need to consider the price of competitors' products when pricing, since this 
affects the demand of products and services, which in turn determines whether craft producers will generate a profit (Obigbemi, 2010).

\section{Marketing strategies in SMEs}

Rijgut (2012) reports that SMEs consider product, price, place and promotion as part of their marketing strategies to succeed in the market. SMEs use quality goods and services, work to understand customers' expectations and employ successful communication strategies as part of their marketing strategies. A study by Pangemanan and Walukov (2018) found that SMEs lag behind in terms of promotion, product quality, price, product diversification, training on product design, management and economies of scale. Their study recommends that SMEs develop marketing networks, improve design and product quality, do promotion and cost control, and undertake product diversification - all of which requires that owner-managers receive training in these areas.

According to Finoti, Didonet, Toaldo and Martins (2017), the formulation of marketing strategies influences the impact of innovativeness on an SME's performance. This implies that SMEs that implement successful marketing strategies will become more innovative which, in turn, will influence their performance. Since the product quality strategy has an impact on the profitability and increased market share of SMEs, such entities must invest in product quality to enhance their profitability (Ebitu, 2016). SMEs need to enhance their brands, since branding plays an important role in public perception (Barbu, Ogarca, \& Barbu 2010). According to Razeghi, Roosta, Alemtabriz and Gharache (2014), "corporate brand building can bring SME differentiation and consistency of image with reality, if SMEs focus on market and innovation in the market, identify the distinctive characteristics of their corporate brand, and assure the consistency and alignment of brand message through comprehensive institutionalization activities".

Čorak and Šnajder (2016) argue that SMEs need internet marketing to successfully compete in the market and could use various online platforms to promote the use of the internet (e.g., banners, sponsor relations and editor comments). Most SMEs were found to use traditional forms of marketing to reach potential customers and entrench their brands, instead of using modern technology (in marketing their products and services) which is effective and less costly to use (Dzisi \& Ofosu, 2014). SMEs need the right mix of media to create the best communication/marketing strategy for the company to sell its products successfully, since there is a strong correlation between marketing strategies and performance in terms of growth in revenue (Ardjouman \& Asma, 2015). SMEs also focus less on marketing planning (Izvercian et al., 2016).

As previously defined by Walker, Mullins and Larréché (2008) and McCarthy and Perreault (1999), a marketing strategy should specify the target market for a product/product line and formulate an integrated, appealing and effective marketing mix which targets the intended consumer.

\section{Research methodology}

This research used conceptual analysis as principal qualitative research technique (Cronin, Ryan \& Coughlan, 2008). Conceptual analysis is the "building block of theory and represents the points around which research is conducted" (Bryman et al., 2014). To ensure a critical analysis and the identification of themes and subthemes, McCarthy and Perreault's (1999) and Walker et al's (2008) interpretations of marketing strategy were used. The themes and sub-themes were identified through a literature review, to answer the following research question (Boghossian 2011):

Which marketing strategies can be used to close the market access gap facing craft producers in South Africa?

To address the above research question, the author will propose marketing strategies aimed at enhancing the marketing of craft products, and thus closing the market access gap that exists in the industry. Whilst craft producers produce unique products, it is important that these products meet the needs of the target market. This implies that craft producers must identify a target market, determine its needs, and then produce products that match those needs. Furthermore, craft producers should determine which prices, marketing communication platforms and distribution channels are appropriate for their products. Possible strategies are discussed next. 


\section{Discussion and recommendations Marketing strategy and craft producers}

As mentioned in the previous section, marketing strategy involves deciding who the target market is, and what marketing mix strategy to aim at that target market. This means that craft producers must have a proper plan in place of how they intend to market their products. Such a plan entails detailing who the target market is, as well as the marketing mix strategy that will be aimed at the selected target market. Craft producers often lack access to market information that can enhance their ability to develop competitive advantage, along with effective marketing strategies and plans. Because they lack access to marketing research information, they tend to be unaware of the markets that might experience a demand for their unique offering (Grobler, 2005, Kaiser \& Associates, 2003), which prevents them from responding to those market needs (Hay, 2008). Collecting market information is crucial for any business, regardless of size, if it is to formulate competitive marketing strategies.

Parnell, Long and Lester (2015) believe that craft producers need to develop marketing capabilities (e.g., knowledge of customers and competitors) and to be able to measure the effectiveness of their selected marketing strategies. Ebersole's (2014) study indicates that SMEs are more concerned about survival issues, which involve searching for new market segments and attempts to increase the size of their total market. Erdem and Erdem (2011) note that many SMEs apply modern marketing approaches which include reviewing customer complaints, specifying demand variety, monitoring competitors' marketing strategies, creating brand names and being sensitive to customer-focused strategies. Komppula and Reijonen (2006), in identifying the factors that have an impact on SMEs performance, list the following (in order of importance): customer orientation, price and accessibility, human resources, finance, marketing channels and product. Since most of these factors are marketing related, it goes without saying that marketing is important for the survival of any business.

\section{Target market and positioning}

There are various market segments in the craft industry. These include consumers who buy crafts for their own consumption; retailers who purchase for resale; tourists who buy crafts as souvenirs and gifts; and businesses that buy crafts for decorations/gifts. There are also different types of retailers that buy craft products, namely craft stores, small interior and gift stores (including boutique stores), large retailers, speciality retailers and destination retailers. Craft producers need to be careful in selecting the market segments they want to pursue (by considering their capabilities). For example, small craft producers might decide not to target retailers owing to their inability to meet the latter's quantity-related demands. However, the same craft producers may decide to focus on boutique retailers that buy small quantities at a time. Craft producers' ability to select the appropriate market segment will determine their eventual success. For example, retailers are known to demand low prices when buying craft products (Makhitha, 2013), but some craft producers are unable to satisfy this demand due to a lack of production scale. On the other hand, many consumers prefer products that tell a story, and are beautiful or unique (Craft Council of Ireland, 2001).

The choice of a specific market segment determines which marketing effort will be directed toward each chosen segment - this is known as target marketing (Craven \& Piercy, 2009:185). Having identified the different market segments that exist in the craft industry, craft producers could then decide which market segment(s) to pursue. One way to achieve this is to match their capabilities with the needs of the selected customer groups. For example, retailers were found to consider the following aspects when selecting which craft producers to buy craft products from: the product is exciting/innovative/interestarousing, shows strong styling and design and is distinctive/unique; the supplier is willing to cooperate with retailers; the product has sales potential; the craft producer's is able to supply products based on customers' demands/requirements; the supplier has capacity and is reliable when it comes to delivery; and the total cost of acquiring the product is reasonable. Studies of tourists' needs found that they look for new, innovative and unique craft products when buying (Kim \& Littrell, 2001). As well as product quality, value for money and lower prices (Makhitha \& Bresler, 2011) they also consider product and package size (Gee, 1987); the price (Peritz, 1993, quoted in Yuksel, 2004) and new/different product ranges (Koc, 2005). Consumers in this country demand low prices when buying crafts, with many treating craft producers as if they are doing them a favour by buying from them (Makhitha, 2013 and 2016). 
Craft producers should therefore decide which segment(s) they want to pursue, based on their ability to meet the various needs of the market segments, before positioning their businesses accordingly. Understanding such needs, however, requires a strategic market analysis of customer needs and their behaviour.

\section{Product strategy}

Whether a product is a totally new innovation, an update of a familiar item or an imitation of a competitor's product, it needs careful planning and development to ensure that it meets customers' needs and wants, that it has a significant competitive advantage, and is accepted in the marketplace (Brassington $\&$ Pettitt, 2007). There is a tendency among craft producers to produce products that are not specific to any particular target market - they produce generic items instead. The majority of craft products are standardised and similar across producers and retailers, leaving very little to distinguish between items sourced from different suppliers (CCDI, 2008). It is of the utmost importance that craft producers understand the needs of their target market, so that they do not waste scarce resources on developing products that are unwanted. This can be achieved in different ways, such as by talking to customers, taking new product ideas or samples to discuss with them or by asking customers what they look for in specific products. It is important to understand that different customers emphasise different product attributes when buying. For example, retailers consider product quality first, followed by products that are exciting and attractive, before looking at the styling and design, the product's distinctiveness/uniqueness and its sales potential. Therefore, craft producers must develop products that match the needs of their target market.

Kinra (1995:41) found that the product attributes which businesses rated higher are product quality and brand image, and that these attributes could be used successfully to position a business. Craft producers need to develop and produce products of high and consistent quality, to satisfy the needs of consumers, retailers and tourists alike. They might upgrade and maintain product quality by ensuring that they use the right kind of raw material, suitable for a higher-quality end product. They could also exercise regular controls over the production process, thus allowing them to deliver product of a more consistent quality (Dhurup \& Makhitha, 2014). In addition, craft producers could apply strict final quality control measures before sending their offerings to retailers. They might also need to emphasise quality throughout their transactions with retailers, who are often on the lookout for new suppliers, and something new and different. Quality assurance and the provision of consistent product quality are necessary components of product development. Most craft products are perceived as having an inherently low value and quality, due to the status of the enterprise, unless they become defined as craft-art and are placed in museums or galleries (DACST, 1997). Craft producers need to change this perception by designing unique products of consistent quality. They could also certify their products with businesses such as the South African Bureau of Standards (SABS) or Proudly SA, which is important especially when selling to retailers (Makhitha, 2013).

Developing similar products with different designs and styles might allow craft producers to target different customers with diverse product requirements. This will also enable producers to provide a broader range of products from which retailers can select what is best suited to their respective stores. Some customers want to carry a specific kind of product design. For example, while the Kim Sacks gallery sells various craft products, it also has a large section displaying ceramic products of different kinds, which are highly exclusive and highly priced. The quality of products needs to merit the price which is charged. Retailers such as Makro and PicknPay Hyper, which are large local stores, sell ceramics that are unique and of high quality yet moderately priced, since their target market is largely the middle-class consumer. Tourists, on the other hand, look for small, easy-to-care-for and good-quality products (Makhitha, 2013; Makhitha \& Dhurup, 2012).

It is essential that craft producers develop and update their products from time to time and keep track of changing trends. In addition to updating product quality, craft producers must also update product designs and styles so as to make products look unique. It is important that they avoid copying other producers' ideas, since this limits their ability to offer styles that are unique and can be identified with their business. Product development must be a continuous exercise that ensures that creativity and innovation remain top priorities. Because of the diversity of craft products, producers should take note of 
any trends affecting the different types of products they produce. For example, the décor retail market is fashion driven and consumers' needs change continuously, while some tourists look for products that reflect the destination area they visited - especially those buying products as souvenirs. Craft producers could ensure that their product designs remain relevant to the traditional, transitional and modern styles, as required by customers: traditional designs are driven by age-old designs, as well as by culture and tradition (Makhitha, 2013); modern designs keep up with changes in the preferences and tastes of craft buyers; while transitional styles are a combination of traditional and modern. This requires continuous analysis of the market, to monitor changes in consumer tastes.

Craft producers could test their products in the market before final development, to determine whether customers like their designs. They could also solicit customer information about their product needs, using word of mouth (Obiri, 2002). Attending training on new product development and design would enable craft producers to understand the processes they need to follow when developing products which, in turn, could reduce the chances of product failure.

Branding could involve the name of the artist (craft producer) being used or featuring on the product. This is important for managing the reputation of the business, since an artist's reputation could be transferred to the products $\mathrm{s} /$ he produces. When marketing to international markets, it is useful for craft producers to use the name of the place/country where the product was made. This combines branding with another (more important) criterion, namely 'place of origin' - an important aspect for craft stores. Some craft producers, such as Carrol Boyes, successfully use branding to make their products unique, and command high prices for their branded products. Branding, product identity and originality are very important in distinguishing products from mass-produced equivalents. The use of suitable packaging and appropriate packing materials for certain products, with the name of the company and contact details of the producer on the packaging, can also reflect the branding to create an impression of quality and identify its source/origins.

Attaching a swing tag serves a number of purposes: contact details can be included, so that customers can identify the craft producers and access information about them. Tourists want details on how the product is made and the type of materials used. This information, if written on a swing tag, can be used for marketing purposes, especially for retailers such as destination stores, speciality stores and gift stores targeting tourists. Other information that can be included on a swing tag are that the product is locally manufactured, or that the craft producers adhere to fair trade principles (e.g., paying a fair wage in the local context, offering employees opportunities for advancement, providing equal employment opportunities for all people [particularly the most disadvantaged] and engaging in environmentally sustainable practices). Some regions are so well marketed and well known that craft producers can use the origin of the product as a marketing tool. For example, the CCDI in South Africa has established the Handmade Cape brand, which communicates the origin of the product and can only be used by craft producers in the Western Cape (Makhitha, 2013).

\section{Marketing communication strategy}

As with product strategy, craft producers need to monitor trends and developments affecting their marketing communication strategy. For example, craft producers could adopt the use of social media, which have taken the market by storm and are being used by businesses, large and small. Craft producers could disseminate information on, for instance, includes price changes, product shortages and date(s) of availability, new products, discontinued items, or changes in packaging, labelling, size and promotional activities. They should ensure that product samples and price lists are readily available at all times, upon the customer's request. Product lists and illustrations are useful to customers such as retailers and tourists. When selling new products, craft producers are expected to supply information on the product and its composition, where ingredients were sourced, the development history, other stockists or the retail price changed by competitors - all of which should be readily available (Makhitha, 2013).

Another opportunity for craft producers lies in disseminating promotional information through the internet, catalogues and trade exhibitions. The internet, while only moderately used by some retailers, can also be a good means of conveying information to retailers and other customers. Craft producers must improve their use of the internet to enhance the image of their business and products. There are many websites (e.g., Buy Africa, Arts Link and SA Arts) that craft producers can approach to market their 
products. SA Handmade and the CCDI also publicise craft producers on their websites, which is something those producers can take advantage of. Craft producers can also use the internet to develop their own websites (which might prove to be an expensive exercise).

Although retailers do not always make use of exhibitions to find producers, the latter could use such events to increase their business exposure and raise awareness by targeting exhibitions aimed at specific retailers and consumers. Exhibitions provide an opportunity for craft producers to network with their counterparts and to identify the latest trends.

The use of promotional DVDs or CDs will allow craft producers to control how their product is made and can 'tell the story' behind their products. Such promotional items could be distributed at exhibitions or via e-mail.

Pricing strategy

Craft producers need to understand the pricing needs of their customers. This requires them to understand what prices different customer segments are willing to pay. For example, the majority of craft retailers operate from major shopping centres that charge high rentals; this, in turn, influences the prices they are willing to pay for craft products. As craft retailers frequently need to visit remote areas to source products, this necessitates financial layouts for transport, accommodation and delivery. The craft producers' selling price should be determined and included in setting what should be competitive prices. To do this, craft producers could analyse competitor prices and determine whether there are standard prices for equivalent products. These costs change from time to time and will require producers to monitor such changes and to adapt their pricing strategies accordingly.

When setting their prices, craft producers must consider the quality of their products, their uniqueness (i.e., compared to the products of their counterparts), the time spent producing them and the quality of the raw materials. Prices should be comparable to those of other craft producers. Information about the prices other craft producers charge can be obtained by scouting out their competitors' work on display at retail stores, or by visiting competitors' workshops to check on, and evaluate, their prices. Craft producers can ensure that they produce unique products by improving their product designs as and when needed and avoiding copying other producers' designs. As mentioned, tourists seek low prices when buying craft products, therefore craft producers should price their products reasonably when targeting this segment of the market.

\section{Distribution strategy}

The distribution of craft products takes place through various channels, including direct sales; craft markets; small retailers/boutiques; wholesalers (which include importers, exporters and agents); national retailers and e-commerce platforms. Direct sales, craft markets and small retailers have been the main forms of retailing in the craft industry for over a decade (DTI, 2005). Since craft producers lack access to markets, they need to formulate an appropriate distribution strategy that will enhance buyers' access to their products. Some producers sell their products at flea markets and/or from their studio/factory point. Although these locations are effective for certain customer groups like tourists (who especially visit flea markets), retailers and businesses that source from craft producers, they might not be ideal for all consumers to visit. Therefore, craft producers first need to assess their market segment(s) to determine the effectiveness of their existing and planned distribution strategies. Buyers might make use of the internet, emails and/or cellphones to place orders. Should email and cellphones be used to place an order, the craft producers will also have to ensure that they have suitable transportation/service providers to deliver products to buyers (Voortman \& Makhitha, 2014). Although social media platforms are wonderful marketing communication tools, they may also be used to place orders and communicate distribution information to customers (Jones, Borgman \& Ulusoy, 2015:625).

Since craft producers run small businesses, some cannot afford their own transport. Possibilities include making use of third-party transport services or selling products excluding transportation costs (i.e., they buyer bears the cost). It is not advisable for craft producers to produce more stock to store in storerooms/warehouses, unless their products are in high demand. However, where craft producers can identify needs and anticipate the demand for certain products, styles and designs, they could produce 
more stock to warehouse (Voortman \& Makhitha, 2014), so that they will have enough to supply craft retailers.

If there is a lack of resources, and craft producers find it difficult to supply the required stock in the right quantities, it may be possible for them to produce items during the low season, for selling during the high season. This requires them to study market demands, so that their products remain relevant throughout the year.

\section{Conclusion}

A marketing strategy, which is important for any business, regardless of size, involves a business deciding on which target market to pursue, before choosing which marketing mix strategy elements will best suit the intended market. Craft producers could therefore not succeed in the market without having an appropriate marketing strategy in place. This is vital if craft producers are to close the market access gap that currently exists in their industry. To close the gap, craft producers need to study the needs of the market, before deciding on the most appropriate market segments they can successfully pursue. This should be followed by the selection of a marketing mix strategy which addresses the needs of the identified market segments. Craft producers need to appropriately formulate tailor-made product, marketing communication, pricing and distribution strategies. It is particularly important for producers who lack resources to focus their marketing efforts on a clearly defined target market. They need to revisit their marketing strategies, to ensure that they develop the right products at the right price for that specific market. They must also attend training on how to market craft products effectively. Existing government marketing support should thus be strengthened to reach the many craft producers who are currently not benefiting from such services.

It is also necessary for government to establish a craft-related website, where producers can market their goods. This website could be used to list craft producers and their products, as well as their contact details. However, it is essential that government make this service accessible to the majority of crafters and not only a handful, which might be the case if only an online platform is used. If government establishes an electronic newsletter or website targeted mainly at craft retailers, in which different craft producers are listed, it could be useful for identifying specific producers and accessing their contact details. It is imperative that such a marketing vehicle target not only a few but the majority of craft producers, so that as many craft retailers as possible have a chance to showcase their goods to the public.

\section{References}

Alsen, K. J. (2007). Strategic marketing: An applied perspective. Boston, MA: McGraw-Hill Irwin.

Ardjouman, D., \& Asma, B. (2015). Marketing management strategies affecting performance of small and medium enterprises (SMEs) in Côte d'Ivoire. International Journal of Business and Social Science, 6(4), 141-150.

Awan, A. G., \& Hashmi, S. (2014). Marketing practices of small and medium-size enterprises: A case study of SMEs in Multan District. European Journal of Business and Innovation Research, 2(6), 9-20.

Barbu, C. M., Ogarca, R. F., \& Barbu, M. R. C. (2010). Branding in small business. Management and Marketing Journal, VIII(S1), S31-S38.

Berthon, P., Ewing, M. T., \& Napoli, J. (2008). Brand management in small and medium-sized enterprises. Journal of Small Business Management, 46(1), 27-45.

Blankson, C., \& Stokes D. (2002). Marketing practices in the UK small business sector. Marketing Intelligence \& Planning, 20(1), 49-61.

Blueprint Strategy \& Policy. (2005). Promotion of small and medium enterprises in the South African chemicals sector: Support for SMEs in the South African Chemicals Sector. Prepared for Chemicals Summit NEDLAC.

Boghossian, P. (2011). Williamson, the a priori and the analytic. Philosophy \& Phenomenological Research, 82(1), 488-497.

Brassington, F., \& Pettitt, S. (2007). Essentials of marketing (2nd ed.). Harlow: Prentice Hall.

Brooksbank, G., Kirby, D., Taylor, D., \& Jones-Evans, D. (1999). Marketing in medium-sized manufacturing firms: The state of the art in Britain, 1987-92. European Journal of Marketing, 33(1/2), 103-120.

Bryman, A., Bell, E., Hirschson, P., Dos Santos, A., Du Toit, J., Masenge, A., Van Aardt, I., \& Wagner, C. (2014). Research methodology: Business and management context. Cape Town: Oxford University Press.

Cape Craft \& Design Institute (CCDI). (2008). 2010 FIFA Football World Cup South Africa: Identifying craft market access opportunities for Western Cape craft producers in the 2010 FIFA World Cup, South Africa and beyond. Accessed 15 November 2013 at

http://www.ccdi.org.za/research-and publications/research/World\%20Cup\%20market\%20opportunities\%20for\%20WC\%20craft $\% 20$ producers.pdf 
Craft Council of Ireland. (2001). Perceptions, attitudes and opportunities. In Critical issues for Irish craft enterprises in 2001: The craft market report. Accessed 15 November 2013 at http://www.worldcat.org/title/craft-marketreport-perceptions-attitudes-and-opportunities-critical-issues-forirish-craft-enterprises-in-2001/oclc/52065517

Čorak, D., \& Šnajder, I. (2016). Marketing strategies and their application in small and medium enterprises emphasizing the modern methods. International Journal - Vallis Aurea, 2(1), 51-60.

Coviello, N. E., Brodie, R. J., \& Munro, H. J. (2000). An investigation of marketing practice by firm size. Journal of Business Venturing, 15(5), 523-545.

Cravens, D. W., \& Piercy, N. F. (2009). Strategic marketing (9th ed.). Boston, MA: McGraw-Hill International Edition.

Cronin, P., Ryan, F., \& Coughlan, M. (2008). Undertaking a literature review: A step-by-step approach. British Journal of Nursing, 17(1), 38-43.

Department of Arts, Culture, Science \& Technology (DACST). (1997, November). Cultural industries growth strategy (CIGS): The SA craft industry report - South Africa. Accessed 15 November 2013 at www.gov.za/documents/download.php?f=70487

Department of Economic Development (DED). (2009). Creating an enabling environment for the growth of KZN craft: KwaZulu-Natal Integrated Craft Hub Business Plan. Final, April

Department of Labour (DoL). (2008). The creative industries in South Africa: Sector studies research project. Accessed 15 November 2013 at

http://www.labour.gov.za/DOL/downloads/documents/research-documents/Creative\% 20Industries_DoL_Report.pdf

Department of Labour. (2011). Labour market review: An investigation into the nature of employment relationships in the South African creative industry. Accessed 15 November 2013 at

http://www.labour.gov.za/DOL/downloads/documents/research-documents/ Creative\%20 Industries _DoL_Report.pdf

Department of Sports, Arts, Recreation \& Culture (DSARC). (2007, October). Gauteng Craft Audit Report [Final draft]. Gauteng: DSARC.

Department of Trade \& Industry (DTI). (2005). Sector Development Strategy: Craft. Accessed 15 November 2013 at http:/ / www.ccdi.org.za/research-and-publications/research/ Customised \%20Sector\%20Programme\%20for\%20Craft.pdf

Dhurup, M., \& Makhitha, K. M. (2014). Reflections on the constraints in entrepreneurial development among emerging survivalist and micro craft enterprises in Gauteng. Journal of Contemporary Management, 1(1), $230-250$.

Dwyer, F. R., \& Tanner, F. T. (2009). Business marketing: Connecting strategy, relationships and learning (4th ed.). Boston, MA: McGraw-Hill Irwin.

Dzisi, S., \& Ofosu, D. (2014). Marketing strategies and the performance of SMEs in Ghana. European Journal of Business and Management, 6(5), 102-111.

Ebersole, J. G. (2014). Twelve causes for small business failures, according to your strategic thinking business coach. Accessed 30 April 2016 at http://www.evancarmichael.com/ Business-Coach/223/Twelve-Causes-For-SmallBusiness-Failures-According-To-Your-Strategic-Thinking-Business-Coach.html

Ebitu, E. T. (2016). Marketing strategies and the performance of small and medium enterprises in Akwa Ibom State, Nigeria. British Journal of Marketing Studies, 4(5), 51-62.

Erdem, F., \& Erdem, S. (2011). Functional strategies and practices of small and medium-sized family businesses. International Journal of Islamic and Middle Eastern Finance and Management, 4(2), 174-185.

Finoti, L., Didonet, S. R., Toaldo, A. M., \& Martins, T. S. (2017). The role of the marketing strategy process in the innovativeness-performance relationship of SMEs. Marketing Intelligence E Planning, 35(3), 298-315.

Frost, A., \& Sullivan. (2005, August). Market feasibility study and business development plan for the handicrafts sector. New Delhi: Export Promotion Council for Handicrafts, India. Accessed 15 November 2013 at http:/ / epch.in/projects/Handicrafts\% 20Final\%20Report_August, \%202005.pdf

Gee, C. Y. (1987). Travel-related shopping and financial services. The Travel Industry, 422-456.

Gilmore, A., Carson, D., \& Grant, K. (2001). SME marketing in practice. Marketing Intelligence E Planning, 19(1), 6-11.

Gray, C., \& Mabey, C. (2005). Management development: Key differences between small and large businesses in Europe. International Small Business Journal, 23(5), 467-485.

Grobler, A. T. (2005). Product development for community-craft projects in Mpumalanga. Unpublished Master's dissertation, University of Pretoria.

Hay, D. (2008). The business of craft and crafting the business: Strategies for success in the rural craft sector. Accessed 4 December 2013 at www.tcd.ufl.edu/.../ BusinesofCraftHandbook-lowresolution.PDF

Hilletofth, P. (2009). How to develop a differentiated supply chain strategy. Industrial Management and Data Systems, 109(1), 16-33.

Hills, G., Hultman, C., \& Miles, M. P. (2008). The evolution and development of entrepreneurial marketing. Journal of Small Business Management, 46(1), 99-112. 
Hutt, M. D., \& Speh, T. W. (2007). Business marketing management: B2B (9th ed.). Mason, OH: Thomson South-Western.

Izvercian, M., Miclea, S., \& Potra, S. (2016). Marketing practices in SMEs. Case Study: Romania vs. Malta, 2016. Procedia - Social and Behavioral Sciences, 221(7), 135-141.

Jones, N., Borgman, R., \& Ulusoy, E. (2015). Impact of social media on small businesses. Journal of Small Business and Enterprise Development, 22(4), 611-632.

Kaiser \& Associates. (2005). Western Cape microeconomic development strategy: Craft sector study. Accessed 4 December 2013 at

http:/ / www.ccdi.org.za/research-andpublications/research/Micro\%20Economic\%20Development\%20Strategy\%20MEDS-\%201.pdf.

Kaiser \& Associates. 2003. Strategic recommendations for the development of the craft industry in the Western Cape: Discussion guide. Prepared for the cape Craft design Institute. CCDI report No. 5, July. Accessed 15 November 2013 at

http:/ /www.ccdi.org.za/research-and-

publications/research/Strategic\%20Recommendations $\% 20$ for $\% 20$ Development $\% 20$ of $\% 20$ the $\% 20$ Craft $\% 20$ Ind ustry \%20in\%20the \%20Western\%20Cape.pdf.

Keller, K. L. (2009). Building strong brands in a modern marketing communications environment.

Journal of Marketing Communications, 15(2/3), 139-155.

Kim, S., \& Littrell, M. A. (2001). Souvenir-buying intentions for self-versus others. Annals of Tourism Research, 28(3), 638-657.

Kinra, N. (1995). Strategic dimensions in marketing planning. Marketing Intelligence $\mathcal{E}$ Planning, 13(4), 34-44.

Koc, E. (2005). New product development in the Turkish tourism market: The case study of football tourism. Journal of Sport Tourism, 10(3), 165-173.

Komppula, R., \& Reijonen, H. (2006). Performance determinants in small and micro tourism business. Tourism Review, 61(4), 13-20.

Lamb, C. W., Hair, J. F., McDaniel, C., Boshoff, C., Terblanche, N., Elliot, R., \& Klopper, H. B. (2011). Marketing (4th ed.). Cape Town: Oxford University Press.

Lekhanya, L. M. (2010). The use of marketing strategies by small, medium and micro enterprises in rural KwaZuluNatal. Unpublished PhD thesis, Durban University of Technology.

Makhitha, K. M. (2013). Buyer behaviour of craft retailers in South Africa. Unpublished PhD thesis, University of Pretoria.

Makhitha, K. M. (2016). Marketing strategies of small craft producers in South Africa: Practices and challenges. Journal of Applied Business Research, 32(3), 1-18.

Makhitha, K. M., \& Bresler, N. (2011). The perceived marketing benefits of the 2010 FIFA World Cup for craft enterprises. African Journal for Physical, Health Education, Recreation and Dance, Supplement, 232-252.

Makhitha, K. M., \& Dhurup, M. (2012). Craft retailers' perceptions of product attributes, price, turnover and profits during the 2010 FIFA World Cup ${ }^{\mathrm{TM}}$. African Journal for Physical, Health Education, Recreation and Dance, Supplement, 124-140.

McCarthy, A., \& Mavundla, K. (2009). Craft as an economic enterprise: Strategies for alternative livelihoods in KwaZulu-Natal. The Small Business Monitor, 5(1), 34-42. Accessed 15 November 2013 at http://www.seda.org.za/Publications/Publications/ SEDA\%20SBM\%202009.pdf

McCarthy, W. D., \& Perreault, E. J. (1999). Basic marketing: A global-managerial approach (13th ed.). Boston, MA: McGraw-Hill.

Moriarty, J., Jones, R., Rowley, J., \& Kupiec-Teahan, B. (2008). Marketing in small hotels: A qualitative study. Marketing Intelligence \& Planning, 26(3), 293-315.

Muhammed, M. Z., Char, A. K., Yasoa, M. R., \& Hassan, Z. (2010). Small and medium enterprises (SMEs) competing in the global business environment: A case of Malaysia. International Business Research, 3(1), 66-75.

Obigbemi, I. (2010). The role of competition on the pricing decision of an organisation and the attainment of the organisational objective. Annals of the University of Petroşani, Economics, 10(1), 229-248.

Obiri, M. N. (2002). Is a market-led approach crucial to art and craft small and micro businesses growth and sustainability in the KwaZulu-Natal Midlands? Unpublished Master's dissertation, University of Natal.

Opuke, R. A., Abratt, R., Bendixen, M., \& Pitt, L. (2005). Communicating brand personality: Are websites doing the talking for food SMEs? Qualitative Marketing Research: An International Journal, 10(4), 362-374.

Pangemanan, S. A., \& Walukov, I. M. (2018). Marketing strategy analysis for small and medium-scale business enterprises (SMEs) for Home Industry Furniture in Leilem, the Regency of Minahasa. Journal of Physics: Conf. Series 953, 1-13.

Parnell, J. A., Long, Z., and Lester, D. (2015). Competitive strategy, capabilities and uncertainty in small and mediumsized enterprises (SMEs) in China and the United States. Management Decision, 53(2), 402-431. 
Razeghi, Y., Roosta, A., Alemtabriz, A., \& Gharache, M. (2014). The role of corporate brand in the entrepreneurial SME's total brand. International Business and Management, 8(2), 120-130.

Rijgut, M. (2012). Marketing strategies adopted by small and medium enterprises in Nairobi central business district: A management research project. Unpublished Master's dissertation, School of Business, University of Nairobi.

Rogerson, C. M. (1999). SMME infrastructure and policy in South Africa. Accessed 4 December 2013 at http://196.4.93.10/compress/e-library/Infrastructure_Mandate_for_Change_1994-1999/Chapter_9.pdf

Sije, A., \& Oloko, M. (2013). Penetration pricing strategy and performance of small and medium enterprises in Kenya. European Journal of Business and Social Sciences, 2(9), 114-123.

Simpson, M., \& Taylor, N. (2002). The role and relevance of marketing in SMEs: Towards a new model. Journal of Small Business and Business Development, 9(4), 370-382.

Simpson, M., Padmore, J., \& Taylor, N. (2001). Marketing in supported employment enterprises (Part II: National survey results). Journal of Small Business and Enterprise Development, 8(4), 301-309.

Siu, W., Fang, W., \& Lin, T. (2004). Strategic marketing practices and the performable of small and medium-sized enterprises (SMEs) in Taiwan. Entrepreneurship \& Regional Development: An International Journal, 16(2), $161-178$.

Smith, D. (1990). Small is beautiful but difficult: Towards cost-effective research for small businesses. Journal of Marketing Research Society, 32(1), 35-51.

Tang, Y., Wang, P., \& Zhang, Y. (2007.) Marketing and business performance of construction SMEs in China. Journal of Business E Industrial Marketing, 22(2), 118-125.

Urbańska, J. (2016). The role of distribution in creating competitive advantage of companies in the SME sector. Advanced Logistic Systems, 4, 131-136.

United Nations (UN). (2010). Creative economy: A feasible development option. Report No. 3. Accessed 4 December 2013 at http://unctad.org/en/Docs/ditctab20103_en.pdf

United Nations Educational, Scientific and Cultural Organisation (Unesco). (1997). International Symposium on Crafts and the International Markets: Trade and Customs Codification. Final report: CLT/CONF/604/7. Accessed 15 November 2013 at http:/ / unesdoc.unesco.org/images/0011/001114/111488eo.pdf

United States Agency for Industrial Development (USAid). (2006). Global market assessment for handicrafts, vol. 1. Final draft, July. Accessed 15 November 2016 at http:/ / pdf.usaid.gov/pdf_docs/PNADN210.pdf

Van Scheers, L. (2011). SMEs' marketing skills challenges in South Africa. African Journal of Business Management, 5(13), 5048-5056.

Venter, P., \& Janse van Rensburg, M. (2009). Strategic marketing: Theory and applications for competitive advantage. Cape Town: Oxford University Press.

Voortman, C., \& Makhitha, K. M. (2014). The alignment of product strategy to supply chain practices of craft businesses in Gauteng Province, South Africa. Journal of Transport and Supply Chain Management, 8(1), 1-11.

Walker, O. C., Mullins, J. W., \& Larréché, J. (2008). Marketing strategy: A decision-focused approach (6 ${ }^{\text {th }}$ ed.). Boston, MA: McGraw-Hill International Edition.

Wesgro. (2000). Wesgro background on the craft industry in the Western Cape. Accessed 4 December 2013 at http:/ / www.ccdi.org.za/research-and-publications/research/Craft \% 20Industry \%20in\%20the\%20Western\%20Cape.pdf

Wong, H. Y., \& Merilees, B. (2005). A rand orientation typology for SMEs: A craft producer research approach. Journal of Product and Brand Management, 14(3), 155-162.

Yuksel, A. (2004). Shopping experience evaluation: A case study of domestic and international visitors. Tourism Management, 25(6), 751-759.

Zontanos, G., \& Anderson, A. R. (2004). Relationships, marketing and small business: An exploration of links in theory and practice. Qualitative Market Research: An International Journal, 7(3), 228-236. 